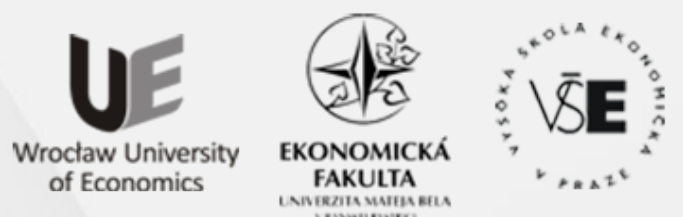

Conference Proceedings

Full TeXT PAPERS

edited by

Zofia Rusnak and Beata Zmyślona

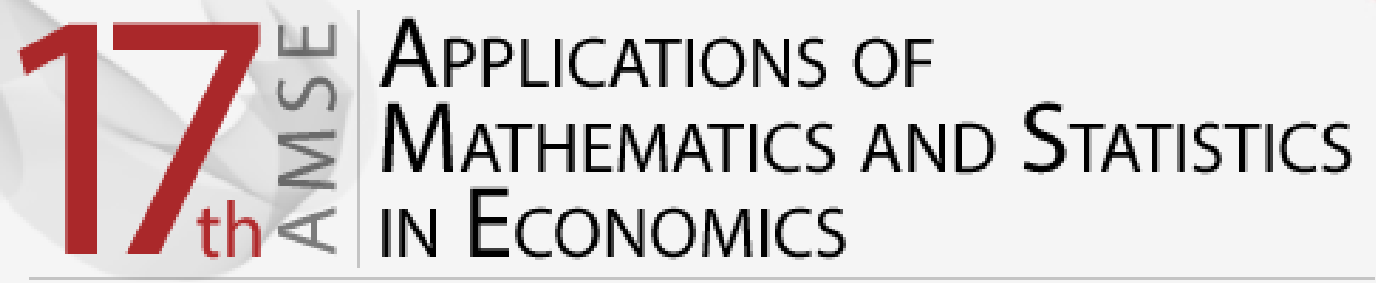

International Scientific Conference | Poland • 27-31 August 2014 
Scientific Committee

Richard Hindls, Stanislava Hronová, Rudolf Zimka, Walenty Ostasiewicz, Emília Zimková, Zofia Rusnak, Martin Bod'a

Organizing Committee

Beata Zmyślona, Cyprian Kozyra, Grzegorz Rogoziński, Kristýna Vltavská

\section{Reviewers}

Milan Bašta, Diana Bílková, Martin Bod'a, Joanna Dębicka, Tomáš Fiala, Jakub Fischer, Stanisław Heilpern, Karel Helman, Lenka Hudrlíková, Miroslav Hužvár, Nikola Kaspř́ková, Alena Kaščáková, Kamil Kladívko, Jindřich Klůfa, Pavol Král', Katarzyna Kuziak, Jana Langhamrová, Ivana Malá, Tomáš Marcinko, Luboš Marek, Miloš Maryška, Petr Mazouch, Zofia Mielecka-Kubień, Witold Miszczak, Petr Musil, Gabriela Nedelová, Walenty Ostasiewicz, Iva Pecáková, Viera Roháčová, Zofia Rusnak, Mária Stachová, Jana Špirková, Šárka Šustová, Jana Tepperová, Vladimír Úradníček, Kristýna Vltavská, Michal Vrabec, Dariusz Wawrzyniak, Henryk Zawadzki, Jaroslav Zbranek, Tomáš Zeithamer, Martin Zelený, Jan Zeman, Rudolf Zimka, Emília Zimková, Pavel Zimmermann, David Žižka

Layout

Martin Bod'a, Beata Zmyślona, Grzegorz Rogoziński

Front page design

Grzegorz Rogoziński

CD cover design

Beata Dębska

Articles published in the form submitted by the authors

All rights reserved. No part of this book may be reproduced in any form or in any means without the prior permission in writing of the Publisher

(C) Copyright by Wrocław University of Economics Wrocław 2014

ISBN 978-83-7695-421-9

Wydawnictwo Uniwersytetu Ekonomicznego we Wrocławiu

53-345 Wrocław, ul. Komandorska 118/120 www.ue.wroc.pl

Sprzedaż książek tel./fax 71 36-80-602

e-mail: econbook@ue.wroc.pl www.ksiegarnia.ue.wroc.pl 


\section{Contents}

Foreword

Diana Bílková: TL-Moments: Analogy of Classical L-Moments

Dagmar Blatná: Application of Robust Regression in the Analysis of Internet Access in European Countries

Martin Bod’a, Mária Kanderová: Rebalancing Issues in Tracking Error Variance Minimization

Martin Bod'a, Viera Roháčová: Application of Six Sigma Ideas to Timing Decisions at Financial Markets

Anton Dekrét, Rudolf Zimka: On the Price Hartwick's Task and Its Inverse in a Dynamic Model of an Economy with Exhaustible Resources

Joanna Dębicka, Agnieszka Marciniuk: Comparison of Reverse Annuity Contract and Reverse Mortgage on the Polish Market.

Petra Dotlačilová, Jitka Langhamrová: The Influence of Mortality Models for the Expected Future Life-time of Older People

Marek Ďurica, Lucia Švábová: Delta and Gamma for Chooser Options.

Vlastimil Farkašovský: New Concept of Pension Funds Performance Evaluation

Albert Gardon: The Normality of Weekly Relative Changes of the Freight Rate in Container Shipping.

Mária Grausová, Miroslav Hužvár, Jana Štrangfeldová: Healthcare Systems Efficiency in the Visegrád Group.

Stanisław Heilpern: Multiple Life Insurance - Pension Calculation

Alena Kaščáková, Gabriela Nedelová: Changes in Slovak Households' Economy

Igor Kollár, Pavol Král', Peter Laco: Methodology for Assessing Website Improvement in Corporate Environment.

Maciej Kostrzewski: Some Method of Detecting the Jump Clustering Phenomenon in Financial Time Series.

Cyprian Kozyra, Beata Zmyślona, Katarzyna Madziarska: Complementary Objective and Subjective Measures of Hospital Services Quality...

Pavol Král', Mária Stachová, Lukáš Sobíšek: Utilization of Repeatedly Measured Financial Ratios in Corporate Financial Distress Prediction in Slovakia

Ivana Malá: The Use of Finite Mixture Model for Describing Differences in Unemployment Duration

Lukáš Malec: Studying Economics and Tourism Industry Relations by Smooth Partial Least Squares Method Depending on Parameter. 
Tomáš Marcinko: Consequences of Assumption Violations Regarding Classical Location Tests.

Edyta Mazurek: The Income Tax Progression Depending on Social Insurance Contribution in Poland.

Petr Musil, Jana Kramulová, Jan Zeman: Regional Consumption Expenditures: An Important Starting Point for Regional Input-output Tables.

Katarzyna Ostasiewicz, Walenty Ostasiewicz: Good Life: From Political to Human Economy

Anna Sączewska-Piotrowska: Analysis of Poverty Transitions in Poland Using Multilevel Discrete-Time Event History Models

Martina Šimková, Petra Švarcová: Disadvantaged University Students in the Czech Republic.

Michal Široký: The Use of Short-term Business Statistics for Quarterly GDP Flash Estimates in the Czech Republic

Zdeněk Šulc, Hana Řezanková: Evaluation of Recent Similarity Measures for Categorical Data.

Lucia Švábová, Marek Ďurica: The Relationship Between the Finite Difference Method and Trinomial Trees

Kristýna Vltavská, Jaroslav Sixta: The Estimation of Final Consumption Expenditures

Lenka Vraná: Business Cycle Analysis: Tracking Turning Points

Janusz Wywiał: On Bayesian Testing in Auditing

Emília Zimková: Window Analysis of Supper-efficiency Change: Case of the Slovak Banking System ....

Beata Zmyślona: Statistical Modelling of the Impact of Diabetes on the Risk of Hospitalization 


\title{
COMPARISON OF REVERSE ANNUITY CONTRACT AND REVERSE MORTGAGE ON THE POLISH MARKET
}

\author{
JOANNA DĘBICKA, AGNIESZKA MARCINIUK \\ Wroclaw University of Economics, Faculty of Management, Information Systems and Finance, \\ Department of Statistics, ul. Komandorska 118/120, 53-345 Wrocław, Poland \\ email: joanna.debicka@ue.wroc.pl, agnieszka.marciniuk@ue.wroc.pl
}

\begin{abstract}
The reverse annuity contracts and reverse mortgages are different and competitive products, often mistakenly identified with each other. The purpose of the article is to compare the products and an overview of their advantages and disadvantages, both for the individual person and married couples. The matrix formulas of the calculating of the benefits value are presented (under the assumption that the future lifetimes of married couples are independent). The calculation of present values is based on the fixed interest rate and the interest rate function depending on time $k$. Moreover the actuarial values are counted on the basis of the Polish Life Tables from 2012.
\end{abstract}

Key words: reverse annuity contract, reverse mortgage, matrix notation.

DOI: 10.15611/amse.2014.17.06

\section{Introduction}

A very big progress in the development of medicine and the growing awareness within the society of healthy nutrition and lifestyle, contributes to the increase of the life expectancy. In the last sixty years, there has followed an increase of Polish life expectancy of about 10 years. The society lives longer and significant decrease of mortality force is observed for people at the retirement age (cf. [Marciniuk 2013]).

The social insurance pensions are low and may be insufficient to survive with dignity. In this context, an important issue is the possibility of obtaining additional financial resources. One of the solutions of obtaining extra financial resources might be to surrender their real estate to a company interested in the acquisition of such a property, in exchange for whole life monthly benefits. Low pensions, high bills for utilities and rent, often high expenditures on medicines make it difficult to maintain a large property, especially in big cities or in a situation when one of the spouses dies. Therefore a few years ago, on the Polish market there appeared the so-called a reverse annuity contract. In return for the transfer of the ownership onto the company, an owner is guaranteed by a notarial act the right to live in property until his death and whole life annuity. The competitive product is supposed to be socalled reverse mortgage. In Poland, the works on the draft regulations finished in October 2013. This solution should be safer for the owner due to control Polish Financial Supervision Authority (PFSA). In this case the owner of the property in return for a monthly pension abandons proprietorship, however, not until after his death (cf. [Shan 2011]).

The reverse annuity contracts and reverse mortgages are different and competitive products, often mistakenly identified with each other. The purpose of the article is to compare the products and an overview of their advantages and disadvantages, both for the individual person and married couples. The matrix formulas of the calculating of the benefits value are 
presented. The benefits are calculated under the assumption that the future lifetimes of married couples are independent. The calculation of present values is based on the fixed interest rate and the interest rate function depending on time $t$. Moreover the actuarial values are counted on the basis of the Polish Life Tables from 2012.

\section{Advantages and disadvantages of both products}

The reverse annuity contract is the benefit, which an owner can receive in exchange for surrender-ring his real estate to a company, i.e. mortgage fund, created especially for this purpose. The owner is guaranteed the right to live in the property until his death by a notarial act (cf. [Borys 2013]). The transfer of the ownership onto the company takes place after signing of a notarial act. The payment of the pension is secured in section IV of the mortgage register. The reverse annuity contract has selling nature and is offered to elderly people. The benefits are paid for $n$ years or the whole life. The value of benefits is determined on the basis of the pensioner's age $x$, the value of real estate $W$ and the further life expectancy. The advantage of this solution is that the company takes responsibility for the valorization of pension, payment of the rent as well as any potential rises in this cost.

The reverse annuity contract is offered since 2005 by a few mortgage funds in Poland. Due to competition, the firms compete in offering various additions to the basic reverse annuity contracts. They take over maintenance fees and their price increases, pay the real estate tax and perpetual usufruct tax, as well as add free health insurance, property insurance, free legal advice, trainings and trips, etc. The funds also bear all costs related to the valuation of real estate and reverse annuity starts. In theory, the agreement is irreversible and the heirs do not have the ability to recover the surrendered property. However, one of mortgage funds gives the possibility of a reversible contract after paying off the received benefits with the interests and any other incurred costs (it is unregulated law, but goodwill of the fund).

Unfortunately, these contracts carry a big risk in a situation when the estate company goes bankrupt. Then the elderly person, who formally is not an owner of the apartment, can be evicted by creditors of the housing. The safety of customers is governed by the Civil Code, in the event of the bankruptcy of the company remains the only investigation of rights through the courts, which for the elderly, sick and lonely people can be a big barrier, not to overcome. This is surely a disadvantage of this product.

For this reason, the society demands regulations and supervision of authority. The competitive product, offered by state institutions, might be the reverse mortgage. It is a product of credit nature offered to both the elderly and the young people. The legislative works on the draft regulations were completed at the end of October 2013 (cf. [Borys 2013]). This product could be offered only by the state financial institutions, controlled by the Polish Financial Supervision Authority and the international financial institutions, subject to the supervisory authorities in the EU Member States (currently still not offered).

In this case, the owner of the property in return for a monthly pension abandons proprietorship, however, not until after his death. Moreover, his heirs have the ability to repay the reverse mortgage to the financial institution and the recovery of housing during the first year after the death of the owner. The security of transactions and the customer is guaranteed by specially created Guarantee Fund overseen by The Polish Financial Supervision Authority. Firstly, the customer must obtain a folder with detailed information and have time to make a decision between 3 to 6 weeks. Secondly, a pensioner may terminate the contract without paying the consequences if the benefit is lower by $15 \%$ than expected and if the benefit is not paid already for 3 months in a row or six months all together (cf. [Borys 2013], [Biznes 
2013]). In addition, the heirs may receive extra money by selling the property at of higher than valued price (cf. [Biznes 2013]). These are the advantages of this product.

Of course, there are also disadvantages. First, the benefit shall be paid in a fixed amount for a pre-determined time and is not valorizated. Secondly, the owner has to pay operating costs, taxes, etc. The amount of the benefit shall be determined only on the basis of the value of the property and the interest rate (in determining the pension the age of the pensioner and the future life expectancy is not taken into consideration (cf. [Davidoff 2009]).

A common feature of the reverse annuity contract and the reverse mortgage is receiving of monthly benefits for the transfer of the real estate to a company. The customer receives only a percentage $\alpha$ of the value of real estate $W$, where $\alpha \in(0 ; 0,5]$ (cf. [Biznes 2013]). Otherwise, they are different products which vary as presented in table 1 . Table 1 is prepared on the basis of [Borys 2013], [Forbes 2013], [Biznes 2013] and [Marciniuk 2014].

Table 1 . The differences between the reverse annuity contract and reverse mortgage

\begin{tabular}{|l|l|l|}
\hline $\begin{array}{l}\text { nature of } \\
\text { product }\end{array}$ & the reverse annuity contract & \multicolumn{1}{|c|}{ the reverse mortgage } \\
\hline age of customer & elderly people & young and elderly people \\
\hline instalment & period or whole life & single or period \\
\hline who can offer & mortgage funds & $\begin{array}{l}\text { the state and the international financial } \\
\text { institutions, subject to the supervisory } \\
\text { authorities in the EU Member States }\end{array}$ \\
\hline $\begin{array}{l}\text { right to the } \\
\text { property }\end{array}$ & $\begin{array}{l}\text { passes after signing of a } \\
\text { notarial act }\end{array}$ & $\begin{array}{l}\text { passes 12 months after the death of the } \\
\text { owner }\end{array}$ \\
\hline $\begin{array}{l}\text { security } \\
\text { regulated by the Act - ensure the } \\
\text { Guarantee Fund subject to the Polish } \\
\text { Financial Supervision Authority }\end{array}$ \\
\hline $\begin{array}{l}\text { breach of } \\
\text { contract }\end{array}$ & $\begin{array}{l}\text { impossible }- \text { the contract is } \\
\text { irreversible }\end{array}$ & possibile in specific cases \\
\hline bonus & yes & no \\
\hline
\end{tabular}

Source: own elaboration

\section{The individual model of reverse annuity contracts and reverse mortgages}

In this section we apply lifetime and certain annuities to determine the value of benefits of reverse annuity contracts and reverse mortgages, which are competing products. We use multiple state modeling which is a stochastic tool for designing and implementing insurance products. Then we adapt the multistate methodology in order to model reverse annuity contracts and reverse mortgage in this paper.

Following [Dębicka 2013], for each insurance contract one can assign so called modified multiple state model. That is, at any time the insured risk is in one of a finite number of states labeled $1,2, \ldots, N^{*}$. Each state corresponds to an event which determines the cash flows (premiums and benefits). In particular, a state may represent such an event as death, disablement etc. Let $S^{*}=\left\{1,2, \ldots, N^{*}\right\}$ be the state space and $T^{*}$ denotes the set of direct transitions between states of the state space. Thus $T^{*}$ is a subset of the set of pairs $(i, j)$, i.e., $T^{*} \subseteq\left\{(i, j) i=j ; i, j \in S^{*}\right\}$. The pair $\left(S^{*}, T^{*}\right)$ is called a modified multiple state model and describes possibilities pertaining to an insured risk. 


\section{APPLICATIONS OF \\ Mathematics and Statistics \\ the IN ECONOMICS}

An insurance contract issued at time 0 (defined as the time of issue of the insurance contract) is considered, and, according to plan, it is terminating at a later time $n$ ( $n$ is the term of policy). We focus on discrete-time model. Let $X^{*}(t)$ denote the state of an individual (the policy) at time $t(t \in \mathrm{T}=\{0,1,2, \ldots, n\})$. Hence the evolution of the insured risk is described by a discrete-time stochastic process $\left\{X^{*}(t) ; t \in \mathrm{T}\right\}$, with values in the finite set $S^{*}$.

It follows from the very definition of the modified multistate model that all types of cash flows at time $k$ deal with the value of $X^{*}(k)$. The individual's presence in a given state or movement (transition) from one state to another may have some financial impact, such as:

- $\quad \pi_{j}(k)$ - a premium amount at some fixed time $k$ if $X^{*}(k)=j$,

- $\quad \ddot{b}_{j}(k)$ - an annuity benefit at time $k$ if $X^{*}(k)=j$

Let $\mathbf{C}=\left(c f_{j}^{*}(k)\right)_{\substack{k=0,1, \ldots n \\ j=1,2, \ldots N^{*}}} \in R^{(n+1) \times N^{*}}$ denote cash flows matrix, where the cash flow $c f_{j}^{*}(k)$ is a sum of inflows representing an income to a particular fund and outflows representing an outgo from a particular fund. Hence $\mathbf{C}=\mathbf{C}_{\mathrm{in}}+\mathbf{C}_{\text {out }}$ and $\mathbf{C}_{\mathrm{in}}$ consists only of incomes to a particular fund and $\mathbf{C}_{\text {out }}$ consist only of outgoes from a particular fund.

Before presenting formulas for annuity benefits for reverse annuity contracts and reverse mortgages, we need to introduce some matrix notation. Let

$$
\begin{aligned}
& \mathbf{S}_{*}=(1,1, \ldots, 1)^{T} \in R^{N^{*}}, \quad \mathbf{S}=(1,1, \ldots, 1)^{T} \in R^{n+1}, \\
& \mathbf{J}_{j}=(0,0, \ldots, \underset{j}{,}, \ldots, 0)^{T} \in R^{N^{*}}, \mathbf{I}_{k+1}=(0,0, \ldots, \underset{k+1}{1}, \ldots, 0)^{T} \in R^{n+1},
\end{aligned}
$$

for each $j=1,2, \ldots, N^{*}$ and $k=0,1, \ldots, n$.

For any matrix $\mathbf{B}=\left(b_{i j}\right)_{i, j=1}^{n+1}$ let $\operatorname{Diag}(\mathbf{B})$ be a diagonal matrix

$$
\operatorname{Diag}(\mathbf{B})=\left(\begin{array}{cccc}
b_{11} & 0 & \cdots & 0 \\
0 & b_{22} & \cdots & 0 \\
\vdots & \vdots & \ddots & \vdots \\
0 & 0 & \cdots & b_{n+1 n+1}
\end{array}\right) .
$$

Additionally, in order to describe the probabilistic structure of $\left\{X^{*}(t)\right\}$, for any moment $k \in\{0,1, \ldots, n\}$ let $p_{j}^{*}(k)=\mathrm{P}\left(X^{*}(k)=j\right)$. We introduce $\mathbf{P}(k)=\left(p_{1}^{*}(k), p_{1}^{*}(k), \ldots, p_{N^{*}}^{*}(k)\right)^{T}$ and

$$
\mathbf{D}=\left(\begin{array}{c}
\mathbf{P}(0) \\
\mathbf{P}(1) \\
\vdots \\
\mathbf{P}(n)
\end{array}\right) \in R^{(n+1) \times N^{*}}
$$

In case of $\left\{X^{\prime \prime}(t)\right\}$ being modelled by a Markov chain [Christiansen 2012, Djehjche 2011], a precise description of the construction of matrices $\mathbf{D}$ and $\mathbf{P}(k)$ is given in [Dębicka 2012].

The following notation is useful to describe the interest rate. Let $\mathbf{V}=\left(1, v, \ldots, v^{n}\right)^{T} \in R^{n+1}$ be the vector of discounting factors. The interest rate may be constant. It can also be a function of time and $v^{k}=e^{-R_{0, k} k}$ where $R_{0, k}$ is the immediate interest rate.

The reverse annuity contract is a product similar to a life annuity due contract in which the owner of the real estate shall be treated as an insured, and the mortgage fund as an insurer. Analogously, the reverse mortgage can be compared to a certain annuity payable in advance 


\section{$17 \backsim$ APPLICATIONS OF \\ Mathematics and Statistics \\ IN ECONOMICS}

International Scientific Conference | Poland • 27-31 August 2014

where the financial institution is treated as an insurance company. For both type of contracts the modified multiple state model has the following form $\left(S^{*}, T^{*}\right)=(\{1,2\},\{(1,2)\})$, where state 1 means that the owner of the real estate is alive and state 2 means that the owner is dead. For such a model matrix $\mathbf{D}$ is designed based on life tables.

In case of $n$-year reverse annuity contract and the $n$-year reverse mortgage

$$
\pi_{j}(k)=\left\{\begin{array}{l}
\alpha W \text { if } j=1 \text { and } k=0 \\
0 \quad \text { besides }
\end{array} \text { and } \quad \ddot{b}_{j}(k)=\left\{\begin{array}{l}
b \text { if } j=1 \text { and } k=0,1, \ldots, n-1 \\
0 \text { besides }
\end{array}\right.\right.
$$

where $W$ is the value of the real estate and $\alpha \in(0,0.5$ ] (cf. [Biznes 2013]).

In case of reverse annuity contract, the value of benefit depends on $\alpha W$ and on the age of the owner of the real estate. It can be counted according to Theorem 1.

Theorem 1. Assume that the principle of equivalence is satisfied. For n-year reverse annuity contract the cash flow matrix is determined for company's mortgage fund and $\alpha W$ is the capital for which the value of benefit is calculated. Let $\ddot{b}_{1}(k)=\ddot{b}$ denote the annuity payable for period $[k, k+1)(k=0,1, \ldots, n-1)$ if the owner of real estate is alive at time $k$. For such reverse annuity contract

$$
\ddot{b}=\frac{\alpha W}{\mathbf{V}^{T}\left(\mathbf{I}-\mathbf{I}_{n+1} \mathbf{I}_{n+1}^{T}\right) \mathbf{D} \mathbf{J}_{1}} .
$$

Proof.

From the company's mortgage fund point of view, the $\alpha W$ is an inflow representing an income to mortgage fund and $\ddot{b}$ are outflows representing an outgo from this fund. Note that the stream of inflows and the stream of outflows moves between the company and the owner of the real estate in the opposite direction. Thus they should assume appropriately positive or negative values; since all payments are considered for one contracting party (company) and

$$
\mathbf{C}=\left(\begin{array}{cc}
\alpha W-\ddot{b} & 0 \\
-\ddot{b} & 0 \\
\vdots & \vdots \\
-\ddot{b} & 0 \\
0 & 0
\end{array}\right)=\left(\begin{array}{cc}
\alpha W & 0 \\
0 & 0 \\
\vdots & \vdots \\
0 & 0 \\
0 & 0
\end{array}\right)+\left(\begin{array}{cc}
-\ddot{b} & 0 \\
-\ddot{b} & 0 \\
\vdots & \vdots \\
-\ddot{b} & 0 \\
0 & 0
\end{array}\right)=\mathbf{C}_{\text {in }}+\mathbf{C}_{\text {out }}
$$

For the multistate insurance, the equivalence principle may be written in the following form (by Corollary 1 in [Dębicka 2013])

$$
\mathbf{V}^{T} \operatorname{Diag}\left(\mathbf{C D}^{T}\right) \mathbf{S}=0 .
$$

Applying (2) to (3), we obtain $\mathbf{V}^{T} \operatorname{Diag}\left(\mathbf{C}_{\text {out }} \mathbf{D}^{T}\right) \mathbf{S}=-\mathbf{V}^{T} \operatorname{Diag}\left(\mathbf{C}_{\text {in }} \mathbf{D}^{T}\right) \mathbf{S}$. Observe that $\operatorname{Diag}\left(\mathbf{C D}^{T}\right) \mathbf{S}=\sum_{k=0}^{n} \mathbf{I}_{k+1} \mathbf{I}_{k+1}^{T} \mathbf{C D}^{T} \mathbf{I}_{k+1}$. Moreover, for matrix $\mathbf{C}_{k}$ (cash flow matrix with 1 in the first $\mathrm{k}$ rows in the first column and zero besides) we have $\operatorname{Diag}\left(\mathbf{C}_{k} \mathbf{D}^{T}\right) \mathbf{S}=\left(\mathbf{I}-\sum_{t=k+1}^{n+1} \mathbf{I}_{t} \mathbf{I}_{t}^{T}\right) \mathbf{D} \mathbf{J}_{1}$. Now it is enough to observe that

$$
\begin{gathered}
-\ddot{b} \mathbf{V}^{T} \operatorname{Diag}\left(\mathbf{C}_{n} \mathbf{D}^{T}\right) \mathbf{S}=-\alpha W \mathbf{V}^{T} \operatorname{Diag}\left(\mathbf{C}_{1} \mathbf{D}^{T}\right) \mathbf{S} \\
-\ddot{b} \mathbf{V}^{T}\left(\mathbf{I}-\mathbf{I}_{n+1} \mathbf{I}_{n+1}^{T}\right) \mathbf{D} \mathbf{J}_{1}=-\alpha W \mathbf{V}^{T}\left(\mathbf{I}-\sum_{k=1}^{n+1} \mathbf{I}_{k} \mathbf{I}_{k}^{T}\right) \mathbf{D} \mathbf{J}_{1}
\end{gathered}
$$




\section{APPLICATIONS OF \\ Mathematics and Statistics \\ IN ECONOMICS}

which in view of $\mathbf{V}^{T}\left(\mathbf{I}-\sum_{k=1}^{n+1} \mathbf{I}_{k} \mathbf{I}_{k}^{T}\right) \mathbf{D} \mathbf{J}_{1}=1$ completes the proof of (1).

In case of reverse mortgage, the value of benefit does not depend on the owner's age and can be counted according to Theorem 2 .

Theorem 2. Assume that the principle of equivalence is satisfied. For n-year reverse mortgage contract the cash flow matrix is determined for company's mortgage fund and $\alpha W$ is the capital for which the value of benefit is calculated. Let $\ddot{b}_{1}(k)=\ddot{b}$ denote the annuity payable for period $[k, k+1)(k=0,1, \ldots, n-1)$ independently of whether or not the owner of the real estate is alive at time $k$. For such reverse mortgage

$$
\ddot{b}=\frac{\alpha W}{\mathbf{V}^{T}\left(\mathbf{I}-\mathbf{I}_{n+1} \mathbf{I}_{n+1}^{T}\right) \mathbf{J}_{1}} .
$$

Proof.

The future cash flows (amounts paid according to mortgage contract) are discounted to the present (to time 0 ) by some interest rate. This produces the present value of cash flows, which is not a random variable (like in reverse annuity contract). In that case, the realization of cash flows does not depend on probabilistic structure of process $\left\{X^{*}(t) ; t \in \mathrm{T}\right\}$ and we have

$$
\sum_{k=0}^{n} v^{k} \sum_{j=1}^{N^{*}} c f_{j}(k)=\sum_{k=0}^{n} \mathbf{V}^{T} \mathbf{I}_{k+1} \sum_{j=1}^{N^{*}} \mathbf{I}_{k+1}^{T} \mathbf{C} \mathbf{J}_{j}=\mathbf{V}^{T}\left(\sum_{k=0}^{n} \mathbf{I}_{k+1} \mathbf{I}_{k+1}^{T}\right) \mathbf{C} \sum_{j=1}^{N^{*}} \mathbf{J}_{j}=\mathbf{V}^{T} \mathbf{C} \mathbf{S}_{*} .
$$

Then the equivalence principle implies that the actual value of the sum of cash flows $c f_{i}^{*}(k)$ arising from the insurance contract equals 0 , so we have

$$
\mathbf{V}^{T} \mathbf{C S}_{*}=0 \text {. }
$$

Applying (2) to (5), we get

$$
\begin{aligned}
\mathbf{V}^{T} \mathbf{C}_{i n} \mathbf{S}_{*} & =-\mathbf{V}^{T} \mathbf{C}_{\text {out }} \mathbf{S}_{*} \\
-\ddot{b} \mathbf{V}^{T}\left(\mathbf{I}-\mathbf{I}_{n+1} \mathbf{I}_{n+1}^{T}\right) \mathbf{S} & =-\alpha W \mathbf{V}^{T}\left(\mathbf{I}-\sum_{k=1}^{n+1} \mathbf{I}_{k} \mathbf{I}_{k}^{T}\right) \mathbf{S}
\end{aligned}
$$

which in view of $\mathbf{V}^{T}\left(\mathbf{I}-\sum_{k=1}^{n+1} \mathbf{I}_{k} \mathbf{I}_{k}^{T}\right) \mathbf{S}=1$ satisfies the proof of (4).

\section{The marriage model of reverse annuity contracts}

In many cases the property owners are couples, therefore an important issue is enabling the marriage reverse annuity contract when both spouses are alive, and then when one of them dies. In the classical approach to two-life annuities, the remaining lifetimes of married couples are assumed to be independent.

The modified multistate model for marriage reverse annuity contract is based on four states: both spouses are alive (1), husband is dead (2), wife is dead (3), both spouses are dead (4) and has the following form (cf. [Dickson, Hardy, Waters 2009])

$$
\left(S^{*}, T^{*}\right)=(\{1,2,3,4\},\{(1,2),(1,3),(1,4),(2,4),(3,4)\}) \text {. }
$$

The value of benefit in such a contract depends on $\alpha W$ and on the age of the spouses, see Theorem 1 in [Dębicka, Marciniuk]. For n-year marriage reverse annuity contract, we have

$$
\dot{b}=\alpha W \frac{\mathbf{V}^{T}\left(\mathbf{I}-\mathbf{I}_{n+1} \mathbf{I}_{n+1}^{T}\right) \mathbf{D} \mathbf{J}_{1}}{\mathbf{V}^{T}\left(\mathbf{I}-\mathbf{I}_{n+1} \mathbf{I}_{n+1}^{T}-\mathbf{I}_{1} \mathbf{I}_{1}^{T}\right) \mathbf{D S}+1} .
$$


where $\ddot{b}_{1}(0)=\ddot{b}$ and $\ddot{b}_{1}(k)=\ddot{b}_{2}(k)=\ddot{b}_{3}(k)=\ddot{b}$ denote the annuity payable if at least one of the spouses lives at time k. Matrix D is constructed for multilife insurance.

We note that (6) still holds for models that take into account additional options, as e.g. divorces.

\section{Numerical examples}

The calculations presented in this section are made by the use of the own programs. It is assumed that the fixed yearly interest rate $i$ equals 3,79\% and the value of the property $W=400000 \mathrm{zl}$. Moreover the Svensson interest rate model $R_{0, k}$ is used. The parameters of function $R_{0, k}$ are estimated by using the least-squares method on the basis of real Polish market data, related to the yield to maturity on fixed interest bonds and Treasury bills from 03.03.2013 ${ }^{1}$. The estimation was made by the use of the Solver in Microsoft Excel. The function $R_{0, k}$ has the following form (cf. [Marciniuk 2009], [De Rezende, Ferreira 2013]).

$$
R_{0, k}=\beta_{0}+\beta_{1} \frac{\tau_{1}}{k}\left(1-e^{-\frac{k}{\tau_{1}}}\right)+\beta_{2}\left(\frac{\tau_{1}}{k}\left(1-e^{-\frac{k}{\tau_{1}}}\right)-e^{-\frac{k}{\tau_{1}}}\right)+\beta_{3}\left(\frac{\tau_{2}}{k}\left(1-e^{-\frac{k}{\tau_{2}}}\right)-e^{-\frac{k}{\tau_{2}}}\right),
$$

where $\beta_{0}=0,0379, \quad \beta_{1}=-0,0016, \quad \beta_{2}=-0,0174, \quad \beta_{3}=0,006, \tau_{1}=1,2242, \quad \tau_{2}=2,5556$.

The fixed interest rate $i$ was chosen $3,79 \%$, because the long-term rate $\beta_{0}$ is equal to 0,0379 . If the interest rate $i$ is higher, the value of annuity will also be higher (cf. [Marciniuk 2014]). The differences between the value of benefits for $i=3,79 \%$ and $R_{0, k}$, determined by the (7) formula, are not significant, therefore the fixed interest rate $i$ or the function $R_{0, k}$ is applied to the calculations.

The yearly value of benefit in case of the individual term reverse annuity contract is presented for a 67-year-old woman and a 67-year-old man on Figure 1. The calculation is made for $n=5,6,7, \ldots, 33$ years. The benefit is lower for the woman. The differences between the annual annuities for the man and for the woman are increasing with the rise of $n$. An older woman will get a lower benefit than an older man at the same age. The differences in the amount of annuity disappear for $n \geq 22$. It is obvious that the benefit of the whole life reverse annuity contract will be the same size as the benefit received from term reverse annuity contract for 22 years.

The yearly value of benefit in case of the individual reverse annuity contract is presented for woman and man (at the age of 67, 70, 75, 80 and 85 years) on Figure 2. The calculation is made for $n=10$ and $n=20$ years and also for the whole life contract in case of Svensson interest rate model. Again, it is possible to notice, that the benefits are lower for the woman and the differences between the annual value of benefits are growing with increasing $n$ and $x$. The differences in the height of annuity are getting smaller for more and more large $n$. For the elderly above the age of 75 years, there is no big difference whether the benefits are paid for 20 years, whether it is the whole life reverse annuity contract.

\footnotetext{
${ }^{1}$ Sources: www.money.pl/pieniadze/bony.przetargi/ and http://bossa.pl/notowania/stopy/rentownosc_obligacji/
} 


\section{APPLICATIONS OF \\ Mathematics and Statistics

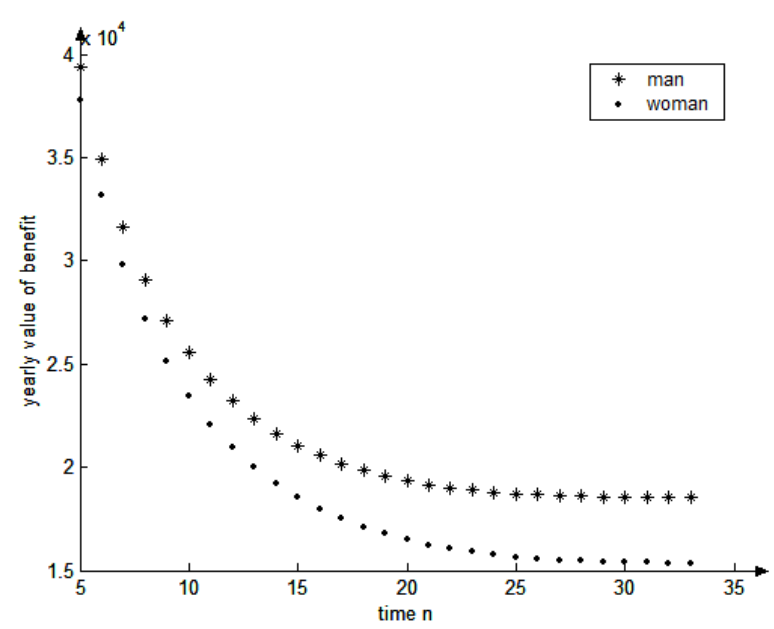

Figure 1 The yearly value of term reverse annuity contract for 67-year-old woman and man for $n=5,6,7, \ldots, 33, W=400000 \mathrm{zl}, i=3,79 \%$.

Source: own elaboration

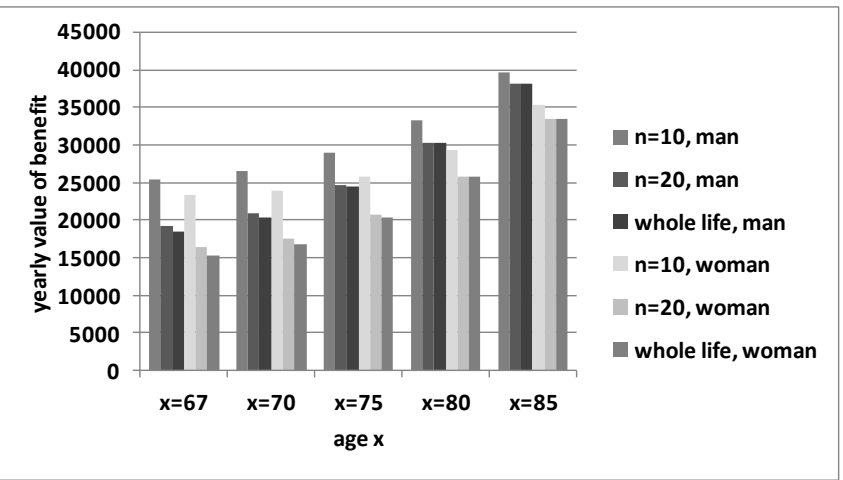

Figure 2 The yearly value of reverse annuity contract for person at age $x=67,70,75,80,85$ for different $n$ and $W=400000 \mathrm{zł}$ in case of Svensson interest rate model.

Source: own elaboration

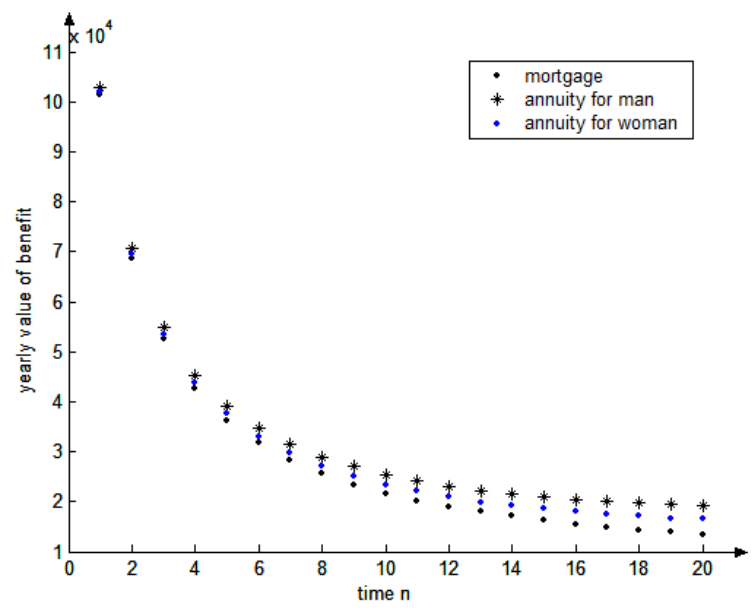

Figure 3 The yearly value of benefits for term reverse annuity contract for a 67-year-old woman and man for $n=1,2, \ldots, 20, W=400000 \mathrm{zl}$ in case of Svensson interest rate model. Source: own elaboration 
On Figure 3 the value of benefits is presented for term individual annuity contract for a 67-year-old person and for the reverse mortgage in case when $R_{0, t}$ is determined by the (7) formula. It is easy to notice that the benefit is the smallest for the reverse mortgage for all $n$. For small $n$ the differences are smaller. It is possible that this contract is more profitable for young people, who need cash fast and they do not sell the property. The benefit in this case does not depend on age. If the reverse annuity contract was offered to young people, this benefit would be lower.

The last part of numerical example is focused on the marriage reverse annuity contract. It is assumed that the future lifetimes of married couples are independent. The article considers a case, when the annuity is paid to both spouses at the same height and after the death of one of them it is still paid to the other spouse in the same amount. The yearly value of these benefits is presented in table 2 for man and woman at the age of 70,75 or 80 years.

Table 2 . The yearly value of benefits for the whole life marriage reverse annuity contract.

\begin{tabular}{|c|c|c|c|}
\hline & \multicolumn{3}{|c|}{ man's age } \\
\hline woman's age & 70 & 75 & 80 \\
\hline 70 & 14752 & 15440 & 15972 \\
\hline 75 & 16198 & 17390 & 18418 \\
\hline 80 & 17560 & 19424 & 21245 \\
\hline
\end{tabular}

Source: own elaboration

The yearly value of reverse annuity contract increases with age. For a younger woman and an older man the benefit is lower than for an older woman and a younger man. The annuity for both spouses at the age of 80 years is higher by $44 \%$ from annuity for both spouses at the age of 70 years, it is about $21 \%$ higher than in a situation where a woman is aged 80 and a man aged 70 years and about 33\% higher than for 70-year-old woman and 80year-old. When a woman is 80 years old and a man 70, the annuity is about $19 \%$ higher than in the situation when both spouses are 70 years old and vice versa, when a man is 80 years old and a woman 70 , the difference is only $8 \%$. The woman's age has the greater impact on the benefit.

\section{Conclusion}

The paper presents and compares two products i.e. the reverse mortgage and the reverse annuity contract on the Polish market. The way of calculation of the benefit using matrix notation in case of a fixed interest rate and the Svensson interest rate model is presented. The analysis of numerical examples leads to the basic conclusion that, although the reverse mortgage has to be safe and competitive for the reverse annuity contract, the annual benefits are always higher for the second product. The value of annuity depends on the age of pensioner and the length of the contract. The benefit is lower for women in case of the individual reverse annuity contract. On the Polish market, a marriage annuity contract is not offered. Therefore, the consideration of this product is something new. The calculations show a greater impact of a woman's age on the amount of benefit. For a younger woman and an older man the benefit is lower than for an older woman and a younger man. All calculations are made by means of own interfaces written in MATLAB. 


\section{APPLICATIONS OF \\ Mathematics and Statistics \\ IN ECONOMICS}

International Scientific Conference | Poland • 27-31 August 2014

\section{Acknowledgements}

The support of the grant scheme NON-STANDARD MULTILIFE INSURANCE PRODUCTS WITH DEPENDENCE BETWEEN INSURED 2013/09/B/HS4/00490 is gladly acknowledged.

\section{References}

1. BORYS A. 17.10.2013. Odwrócona hipoteka i renta dożywotnia, warto czy nie? [cit. 28.10.2013] http://www.polskieradio.pl/42/273/Artykul/958255,Odwrocona-hipoteka-irenta-dozywotnia-warto-czy-nie.html.

2. CHRISTIANSEN M.C. 2012. Multistate models in health insurance. Asta-Advances in Statistical Analysis, 2012, vol. 96, iss. 2, pp. 155-186.

3. DAVIDOFF T. 2009. Housing, Health, and Annuities. Journal of Risk and Insurance, 2009, vol. 76, iss. 1, pp. 31-52.

4. DE REZENDE R. B., FERREIRA M.S. 2013. Modeling and Forecasting the Yield Curve by an Extended Nelson-Siegel Class of Models: a quantile autorgression approach. Journal of Forecasting, 2013, vol. 32, iss. 2, pp. 111-123.

5. DĘBICKA J. 2012. Modelowanie strumieni finansowych w ubezpieczeniach wielostanowych. Wydawnictwo Uniwersytetu Ekonomicznego we Wrocławiu. ISBN: 987-83-7695-183-6.

6. DEBBICKA J. 2013 An approach to the study of multistate insurance contracts. Appl. Stochastic Models Bus. Ind., 2013, vol. 29, iss. 3, pp. 224-240.

7. DĘBICKA J., MARCINIUK A. An approach to the study of multilife reverse annuity contracts - manuscript.

8. DJEHJCHE B. 2011. Actuarial mathematics for life contingent risks. Scandinavian Actuarialn Journal, 2011, iss. 4, pp. 318-328.

9. Gotowy projekt ustawy o odwróconym kredycie hipotecznym. [cit. 30.10.2013] http://www.fobres.pl/gotowy-projekt-ustawy-o-odwroconym-kredyciehipotecznym,artykuly, 164584,1,1.html. 15.10.2013.

10. DICKSON D. C. M., HARDY M. R., WATERS H. R. 2009. Actuarial Mathematics for Life Contingent Risks. Cambridge Un. Press, Cambridge. ISBN: 978-0-521-11825-5.

11. MARCINIUK A. 2009. Nielosowe modele natychmiastowej stopy procentowej i ich zastosowanie w klasycznych ubezpieczeniach życiowych, Ekonometria 27, PN Wroclaw University 84, Wrocław: Wroclaw University Press, 2009, pp. 112-127.

12. MARCINIUK A. 2013. Długowieczność i instrumenty finansowe związane z długowiecznością. Prace Naukowe nr 309, Wrocław: Wroclaw University Press, 2014, pp. 100-115. (in printed).

13. MARCINIUK A. 2014. Renta hipoteczna a odwrócony kredyt hipoteczny na rynku polskim. (in printed).

14. Ruszyły prace nad przepisami o odwróconym kredycie. [cit. 28.10.2013] http://biznes.interia.pl/finanse-osobiste/news/ruszyly-prace-nad-przepisami-oodwroconym-kredycie, 1937734, 4141. 24.07.2013.

15. SHAN H. 2011. Reversing the Trend: The Recent Expantion of the Reverse Mortgage Market. Real Estate Economic, 2011, vol. 39, iss. 4, pp. 743-768. 